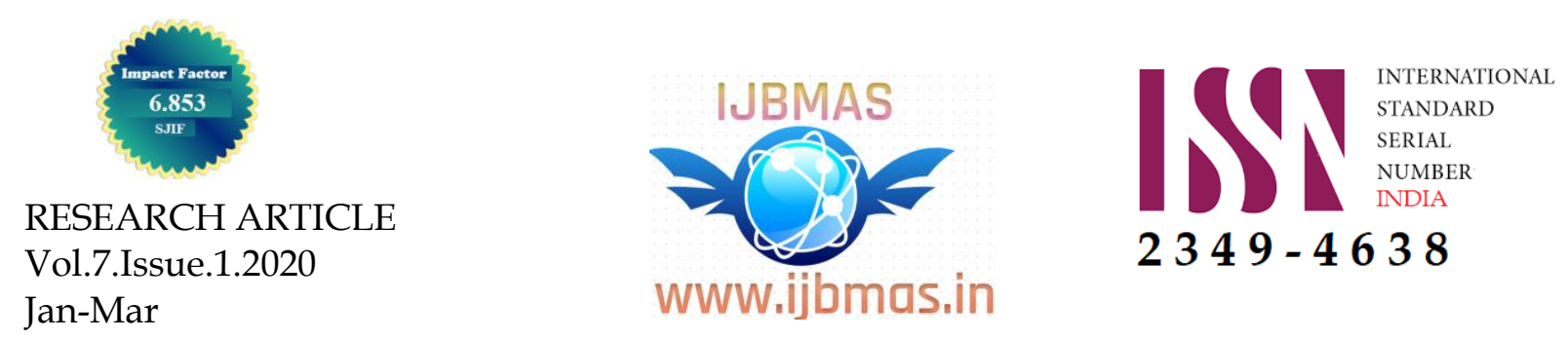

INTERNATIONAL JOURNAL OF BUSINESS, MANAGEMENT AND ALLIED SCIENCES (IJBMAS)

A Peer Reviewed and refereed Journal

\title{
INCOME AND EMPLOYMENT GENERATION THROUGH SHGs - A STUDY IN MAHABUBNAGAR DISTRICT OF TELANGANA
}

\author{
Dr. SUSHILA ALEME1, Dr. YELLAIAH JANGATI ${ }^{2}$ \\ ${ }^{1}$ Lecturer in Economics, Telangana Model School and Junior College, Bhudan Pochampally, \\ Yadadri Bhongir, Telanagana State \\ 2Lecturer in Economics, Telangana Model School and Junior College, Vallala, Nalgonda, \\ Telanagana State \\ DOI: $10.33329 /$ ijbmas.7.1.30
}

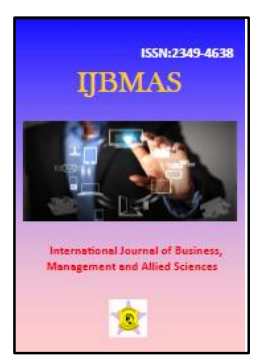

\section{ABSTRACT}

The striking functional feature of the SHGs is that it provides access to credit for the poor with minimum affordable cost and the loans are properly utilized and repayments are prompt. The SHGs took up issues like wife battering, child marriages and harassment by the employers which is considered as best suited groups to take up gender linked. They can also take up general community issues. Economic empowerment to motivate to make decision, better status and role in household increased self-confidence, etc. The issues related to support to micro entrepreneurs, poverty alleviation, financial, gender development etc. The variables which are Age, Education, Occupation, and Size of employment, Income and investments have impact of SHGs on their livelihood. But statistically Income and Investment are significant. These variables are impact on SHGs livelihood.

\section{INTRODUCTION}

The Government of India and all the state Governments have been implementing various programmes for rural development. This problem has been severe and acute in the recent past. The latest statistics relating to the Indian Economy indicate that about $26 \%$ people of the total population in the country hail from the rural poor. Considering the gravity and intensity of the problem, the central and state governments are implementing various developmental programmes and schemes for the development and welfare of the weaker sections in the country.

The main objectives of the SHGs are (1) to promote employment and educational opportunities for rural women, (2) to find out opportunities for the upliftment of women indusial employment. (3) and to help the economical development with no consideration of cast and religion factors. The main functions of SHGs are (a) holding periodical meetings for decision making through group meetings (b) creating a common fund by the members with regular savings (c) and repaying loan amount in the given time. 

REVIEW OF THE EARLIER STUDIES

Piyanka dongre and Ajay pethe (2020) On examining the awareness of SHG and micro finance among the respondents, it is concluded that the respondents are well aware of the concepts of micro finance through SHG viz. awareness about constitution of the group, bookkeeping and accounts, group management and banking procedures. Among the four dimensions of awareness, awareness on book keeping and accounts is very high followed by group management aspects, group constitution and banking procedure aspects.

R.Das Gupta The author suggested that the first task of the government is to bring legislation for MFIs underlining 1. the definition of microfinance in both qualitative and quantitative terms 2 . A new registration act indicating capital requirement, regulatory and supervision authority,3. Character of the MFI in terms of nature of operation to the carried out directly or indirectly, clientele group, area of operation, sources of funds, use of surplus, income tax rules, governance etc. The second and a very important task of the government is to take an active part in the development of human capital for MFIs.

Madhura Swaminathan has opined that micro credit has been receiving a significant amount of attention all over the world, especially in developing countries. The Indian banking system has many weaknesses, and in many ways, has failed to fulfill the objectives of social and development banking in rural India. The present overhaul of policy in the era of financial liberalization is a further set back to the expansion of the rural credit. The banking system can and must improve its functioning by working with local governments and local voluntary organizations. Costs for bank as well as for borrowers can be lowered when bank works in an innovative way with Panchayats and SHGs.

MD. Saiful Islam has concluded that none can deny the socio-cultural and political impact of micro credit program of Grameen Bank at least at the micro level. Still now Grameen Bank encourages micro enterprises and critics are sceptical how Grameen Bank can contribute to the national development without large-scale industrialization and mass employment.

Karmakar, K G had analysed on existing credit delivery system in India with special reference to the credit needs of rural poor and role of SHGs in making the delivery system more effective and viable. He also reviewed the depth of outreach in microfinance, which usually starts and often ends with loan size.

Bavaiah and Narasimha Rao had observed that the women empowerment and its linkages with microfinance in Ethiopia. They have focused on the decision making power of women in terms of political participation, taking decision of financial related, and limit to the financial resources. They have observed that women are agents of development. Therefore, microfinance might be one of the factors responsible for women empowerment and development process. The study revealed that the percentage of women MFIs clients is the highest in South and East Asian countries (94.2 percent) and the least in Eastern Europe and Central Asian countries (62 percent).

\section{INCOME AND EMPLOYMENT GENERATION}

Economic empowerment to motivate to make decision, better status and role in household, increased self confidence, etc. The issues related to support to micro entrepreneurs, poverty alleviation, financial, gender development etc. There is however, no proper definition of micro finance. The task force on support policy and Regulatory Framework Micro finance has defined micro finance as "Provision of credit, thrift and other financial services. But the task force has not defined any amount.

\section{OBJECTIVES OF THE STUDY}

- To determine the factors contributing to the income of the self - help group members.

- To identify the factors contributing to the employment generation of the self - help group members. 


\section{METHODOLOGY}

We use the multi stage random sampling method in the selection of micro finance institutions area and beneficiaries. In the first stage will select micro finance instituting which is providing loans in the poor people. In the second stage Mahabubnagar district has been selected it is due to the concentration of large number of beneficiaries in the district. In the third stage among the 64 mandals in the district, 4 mandals have been randomly selected for the collection of primary data. The sample respondents selected mostly by adhering to the principles of stratified random sampling. The criteria for stratification are social status and nature of activity.

\section{DATA SOURCES}

The study makes use of both primary and secondary sources. Administering a pre-designed questionnaire among the MFI beneficiaries collects the primary data. The secondary data were collected from the annual reports of sample Micro enterprises and the reports published by NABARD for the years concerned.

\section{STATISTICAL TOOLS}

The present study used various tools of statistics including simple percentages, frequency distribution, mean, standard deviation; chi-square statistic, correlation co-efficient and simple regression are employee.

Table 1: Major Source of Income to the Household

\begin{tabular}{|l|l|l|l|}
\hline Sl. no & $\begin{array}{l}\text { Major Source of Income to the } \\
\text { Household }\end{array}$ & Respondents & Percentage \\
\hline 1 & Own Cultivation & 90 & 22.5 \\
\hline 2 & Tenant Cultivation & 13 & 3.2 \\
\hline 3 & Allied Agricultural Activity & 24 & 6.0 \\
\hline 4 & Agricultural Labour & 165 & 41.2 \\
\hline 5 & Nonfarm self employed & 60 & 15.0 \\
\hline 6 & Non-farm wage/salaried & 48 & 12.0 \\
\hline & Total & 400 & 100 \\
\hline
\end{tabular}

Source: Field Study

The above table shows that Major Source of Income to the Household. Among 400 respondents 22.5 percentages of the respondents are having Own land cultivation, 3.2 percentages of the respondents are Tenant Cultivation, allied Agricultural activity, 41.2 percentages of the respondents are agricultural labour, 15 percentages of the respondents are non form self employed and 12 percentages of the respondents are nonfarm wage/ salaried.

Table 2: Land Owned

\begin{tabular}{|l|l|l|l|}
\hline Sl. no & Land Owned & Respondents & Percentage \\
\hline 1 & Irrigated & 102 & $25.5 \%$ \\
\hline 2 & Un-irrigated & 88 & $22.0 \%$ \\
\hline 3 & Not Applicable & 210 & $52.5 \%$ \\
\hline & Total & 400 & 100.0 \\
\hline
\end{tabular}

Source: Field Study

The above table shows that land owned by the households. Among the 400 respondents 25.5 percentages of the respondents are having irrigated land, 22 percentages of the respondents are having un-irrigated land and 52.5 percentages of the respondents are doesnot have land. 
Table3: Occupation of the respondents

\begin{tabular}{|l|l|l|l|}
\hline 1. no & Primary Occupation & Respondents & Percentage \\
\hline 1 & Large Farmer & 16 & $4.0 \%$ \\
\hline 2 & Medium Farmer & 15 & $3.8 \%$ \\
\hline 3 & Small Farmer & 44 & $11 \%$ \\
\hline 4 & Marginal Labour & 41 & $10.2 \%$ \\
\hline 5 & $\begin{array}{l}\text { Allied Agricultural } \\
\text { Activity/Tenant }\end{array}$ & 34 & $8.5 \%$ \\
\hline 6 & Agricultural Labour & 112 & $28.0 \%$ \\
\hline 7 & Non-farm self employed & 41 & $10.2 \%$ \\
\hline 8 & Non-farm wage/salaried & 97 & $24.2 \%$ \\
\hline
\end{tabular}

Source: Field Study

The above table shows that Primary Occupation of the respondents. Among the 400 respondents 4 percentages of the respondents are large farmer, 3.8 percentages of the respondents are Medium farmers, 10.8 percentages of the respondents are Small Farmers, 10.2 percentages of the respondents are Marginal Labour, 8.5 percentages of the respondents are Allied Agricultural Activity/Tenant, 28 percentages of the respondents are Agricultural Labour, 10.2 percentages of the respondents are Non-farm self employed, 24.2 percentages of the respondents are Non-farm wage/salaried.

Table 4: Subsidiary Occupation of the Respondents

\begin{tabular}{|l|l|l|l|}
\hline Sl. no & Subsidiary Occupation & Respondents & Percentage \\
\hline 1 & Marginal Labour & 7 & $1.8 \%$ \\
\hline 2 & $\begin{array}{l}\text { Allied Agricultural } \\
\text { Activity/Tenant }\end{array}$ & 62 & $15.5 \%$ \\
\hline 3 & Agricultural Labour & 59 & $14.8 \%$ \\
\hline 4 & Non-farm self employed & 52 & $13.0 \%$ \\
\hline 5 & Non-farm wage/salaried & 104 & $26.0 \%$ \\
\hline 6 & Unemployed & 116 & $29.0 \%$ \\
\hline & Total & 400 & $100.0 \%$ \\
\hline
\end{tabular}

Source: Field Study

The above table shows that Subsidiary Occupation of respondents. Among the 400 respondents 1.8 percentages of the respondents are Marginal Labour, 15.5 percentages of the respondents are Allied Agricultural Activity/Tenant, 14.8 percentages of the respondents are Agricultural labour, 13 percentages of the respondents are Non-farm self employed, 26 percentages of the respondents are Non-farm wage/salaried and 29 percentages of the respondents are Unemployed. 
Table 5: Income of the household

\begin{tabular}{|l|l|l|l|}
\hline Sl. no & Own Income & Respondents & Percentage \\
\hline 1 & Upto 50000 & 303 & $75.8 \%$ \\
\hline 2 & $50001-100000$ & 82 & $20.5 \%$ \\
\hline 3 & Above 100000 & 15 & $3.8 \%$ \\
\hline & Total & 400 & 100.0 \\
\hline
\end{tabular}

Source: Field Study

The above table shows that Income of the respondents. Among the 400 respondents $75.8 \%$ percentages of the respondents are having income upto 50000, 20.5\% percentages of the respondents are having income 50001 to 100000 , and remaining $3.8 \%$ percentages of the respondents are having income above 100000.

Table 6: DECISION TAKEN BY THE RESPONDENT IN THE FAMILY

\begin{tabular}{|l|l|l|l|}
\hline SI No & Response & Before Joining & After Joining \\
\hline 1 & Take Decision & $\begin{array}{l}150 \\
(37.5 \%)\end{array}$ & $\begin{array}{l}280 \\
(70 \%)\end{array}$ \\
\hline 2 & Do Not Take Decision & 250 & 120 \\
& & $(62.5 \%)$ & $(30 \%)$ \\
\hline 3 & Total & 400 & 400 \\
\hline
\end{tabular}

Source: Primary Data

It is seen from Table 6 that just 150 (37.5 percent) individuals have indicated positive reaction towards taking choices on vital issues previously joining the SHGs. In any case, 280 individuals (70 percent) have appeared positive reaction towards taking the choices on essential issues subsequent to joining the SHGs.

Table 7: Loan amount limits provided by SHG

\begin{tabular}{|l|l|l|l|}
\hline Sl. No. & Loan limit & No. of SHGs & $\%$ Total \\
\hline 1. & $1001-10000$ & 18 & $45 \%$ \\
\hline 2. & $10001-20000$ & 9 & $22.5 \%$ \\
\hline 3. & $20001-30000$ & 7 & $17.5 \%$ \\
\hline 4. & $30001-40000$ & 4 & $10 \%$ \\
\hline 5. & $40001-50000$ & 2 & $5 \%$ \\
\hline & Total & 40 & $100 \%$ \\
\hline
\end{tabular}

Source: Fieldwork,

The table1 7 demonstrates that the advance given by SHGs to its individuals extended from Rs.100150,000. In this investigation it was discovered that 45\% SHGs could give credit of Rs.1001-10000 to its individuals, 22.5\% SHGs loan advance of Rs.10001-20000, 17.5\% SHGs gave advance of Rs.2000130000, 10\% gave advance of Rs.30001-40000 and 5\% SHG offered advance of Rs.40001-50000. The information demonstrates that SHGs had gathered great measure of investment funds and could give 
advances to its individuals. The SHGs giving advances running from 9001- 20,000 were more on the grounds that such credits could be effectively reimbursed by the individuals instead of bigger sums.

Table 8: Loans distribution to SHG members

\begin{tabular}{|l|l|l|l|}
\hline S1. No. & Distribution of loans & No. of respondents & $\%$ Total \\
\hline 1. & According to the need of members & 360 & 90 \\
\hline 2. & Equally distributed among all & 22 & 5.5 \\
\hline 3. & Leaders decides who should get & 18 & 4.5 \\
\hline & Total & 400 & 100 \\
\hline
\end{tabular}

Source: Fieldwork,

Table 8 demonstrates that $90 \%$ respondents kept up that the credits inside the SHG are appropriated by the requirements of the individuals, $5 \%$ respondents said that advances are similarly circulated among the individuals and $4.5 \%$ uncovered that the pioneers settled on who ought to get the advance. The information gathered, uncovers that in the greater part of the SHGs, advances are given by the requirements of the individuals and the term for reimbursement of advances is settled by the SHGs according to the measure of advance taken.

Table 9: Income generating products of SHG

\begin{tabular}{|l|l|l|l|}
\hline S1. No. & Products made by SHG & No. of SHGs & $\%$ Total \\
\hline 1. & $\begin{array}{l}\text { Agricultural produce (vegetables, ginger cultivation, } \\
\text { floriculture) }\end{array}$ & 12 & $30 \%$ \\
\hline 2. & Livestock/Poultry/Dairy & 10 & $25 \%$ \\
\hline 3. & Local snacks and pickle & 8 & $20 \%$ \\
\hline 4. & Handicrafts & 7 & $17.5 \%$ \\
\hline 5. & Bakery & 2 & $5 \%$ \\
\hline 6. & Nil & 1 & $2.5 \%$ \\
\hline & Total & 40 & $100 \%$ \\
\hline
\end{tabular}

Source: Fieldwork,

The table 9 represents that $30 \%$ SHGs created farming items, for example, vegetables, ginger and blooms, 25\% have domesticated animals, for example, goat, pig, bovine, poultry, $20 \%$ make nearby bites, honeycomb, custom made chips, $17.5 \%$ did fitting and made conventional handiworks, for example, bamboo make, sacks, cover, $5 \%$ SHGs were occupied with pastry shop and delivered bun, bread, pizza and so forth and $2.5 \%$ SHG did not do any financial exercises.

Table 10 Agency wise mobilisation of SHG

\begin{tabular}{|l|l|l|l|}
\hline S1. No. & Mobilization & No. of SHGs & $\%$ Total \\
\hline 1. & Society for Elimination Rural Poverty (SERP) & 38 & $95 \%$ \\
\hline 2. & NGO & 0 & $0 \%$ \\
\hline 3. & Bank officials & 02 & $05 \%$ \\
\hline & Total & 40 & $100 \%$ \\
\hline
\end{tabular}

Source: Fieldwork, 
It was discovered that out of 40 SHGs that were talked with, most extreme number of SHGs were activated by Society for Elimination Rural Poverty (SERP), for example 95\% SHGs, trailed by 5\% of SHGs shaped by Bank authorities. It was seen that practically the majority of the SHGs met were established under SGSY plot consequently the executing office for example SERP's commitment in activating SHG apparently is more prominent when contrasted with NGO and Banks.

Table 11: Level of cooperation within the SHG

\begin{tabular}{|l|l|l|l|}
\hline Sl. No. & Level of Cooperation & No. of respondents & $\%$ Total \\
\hline 1. & All members are cooperative & 392 & $98 \%$ \\
\hline 2. & Some members are cooperative & 08 & $02 \%$ \\
\hline 3. & None are cooperative & 0 & 0 \\
\hline & Total & 400 & $100 \%$ \\
\hline
\end{tabular}

Source: Fieldwork,

The field information shows that $98 \%$ respondents saw that, all individuals in their gathering are agreeable though $2 \%$ respondents expressed that a few individuals are not helpful and $0 \%$ respondents communicated that their gathering were not helpful. Accordingly, the examination connotes that ladies who are individuals from SHGs are generally agreeable with different individuals in the gathering. The respondents who guaranteed that a few individuals in their SHGs are not helpful on the grounds that the individuals in their gathering don't go to gatherings, neglect to partake in financial, social and pay creating exercises of the gathering and show absence of enthusiasm because of inward clash.

Table 12: Transparency within the SHG

\begin{tabular}{|l|l|l|l|}
\hline S1. No. & Transparency & No. of respondents & $\%$ Total \\
\hline 1. & The group is transparent & 380 & $95 \%$ \\
\hline 2. & The group is sometimes not transparent & 18 & $4.5 \%$ \\
\hline 3. & Transparency is not maintained & 02 & $0.5 \%$ \\
\hline & Total & 400 & $100 \%$ \\
\hline
\end{tabular}

\section{Source: Fieldwork,}

The field information shows that $95 \%$ respondents saw that, all individuals in their gathering are agreeable though $4.5 \%$ respondents expressed that a few individuals are not helpful and the same number of as $0.5 \%$ respondents communicated that their gathering were not helpful.

Table 13: Decision making within the SHG

\begin{tabular}{|l|l|l|l|}
\hline Sl. No. & Decision made by & No. of respondents & $\%$ Total \\
\hline 1. & All members & 380 & $95 \%$ \\
\hline 2. & Some members & 16 & $04 \%$ \\
\hline 3. & By the leaders only & 04 & $1 \%$ \\
\hline & Total & 400 & 100 \\
\hline
\end{tabular}

\section{Source: Fieldwork,}

The information infers that $95 \%$ respondents concurred that basic leadership inside the gathering is collectively done thinking about the assessment everything being equal, $4 \%$ respondents kept up that 
choice inside the gathering is taken just by a few individuals and $1 \%$ respondents said that choices inside the SHG are taken just by pioneers. Nonetheless, the investigation proposes that basic leadership is done on the whole by all individuals in a large portion of the gatherings.

Table 14 Marketing of economic products of SHG

\begin{tabular}{|l|l|l|l|}
\hline Sl. No. & Marketing Centers & No. of SHGs & $\%$ Total \\
\hline 1. & Exhibitions/fair & 1 & $2.5 \%$ \\
\hline 2. & Supermarket & 4 & $10 \%$ \\
\hline 3. & Rural Products Marketing Centres & 2 & $5 \%$ \\
\hline 4. & Own Shop & 3 & $7.5 \%$ \\
\hline 5. & Within the village/ local market & 30 & $75 \%$ \\
\hline 6. & Nil & 0 & $0 \%$ \\
\hline & Total & 40 & $100 \%$ \\
\hline
\end{tabular}

\section{Source: Fieldwork,}

In this examination 2.5\% SHGs sold their items in reasonable and shows, $10 \%$ in general stores another 5\% sold their create in Rural items showcasing focuses built up by the legislature in their towns and neighbouring regions, $7.5 \%$ sold their financial items in their very own shops, $75 \%$ advertised it inside the town or nearby market and $0 \%$ did not take up any monetary exercises because of absence of agreement among the individuals about financial action. The SHGs were occupied with financial exercises dependent on their preparation and aptitudes.

Table 15: Monthly income through economic products

\begin{tabular}{|l|l|l|l|}
\hline Sl. No. & Income per month & No. of SHGs & $\%$ Total \\
\hline 1. & Rs.1001-2000 & 16 & $40 \%$ \\
\hline 2. & Rs. $2001-3000$ & 12 & $30 \%$ \\
\hline 3. & Rs. $3001-4000$ & 10 & $25 \%$ \\
\hline 4. & Rs. $4001-5000$ & 01 & $2.5 \%$ \\
\hline 5. & Rs. $5001-6000$ & 0 & $0 \%$ \\
\hline 6. & Rs. $6001-7000$ & 0 & $0 \%$ \\
\hline 7. & Rs. $7001-8000$ & 0 & $0 \%$ \\
\hline 8. & More than Rs. 8000 & 0 & $0 \%$ \\
\hline 9. & Nil & 01 & $2.5 \%$ \\
\hline & Total & 40 & 100 \\
\hline
\end{tabular}

\section{Source: Fieldwork,}

The information speaks to that $40 \%$ SHG had created a salary running from Rs. 1001- 2000, 30\% SHG had salary of Rs.2001-3000, 25\% every one of the SHG have pay extending from Rs.3001-4000, Just $2.5 \%$ SHG had pay of Rs, $4001-5000$ another $2.5 \%$ bunches had not taken up salary producing exercises. 
Table 16: Contribution of members in income generating activities

\begin{tabular}{|l|l|l|l|}
\hline S1. No. & Contribution & No. of respondents & $\%$ Total \\
\hline 1. & All members & 380 & $95 \%$ \\
\hline 2. & Some members & 15 & $3.75 \%$ \\
\hline 3. & Very few members & 05 & $1.25 \%$ \\
\hline & Total & 400 & $100 \%$ \\
\hline
\end{tabular}

\section{Source: Fieldwork,}

Table 4.24 demonstrates the commitment of SHG individuals in monetary exercises. It portrays that 380 respondents $(95 \%)$ guaranteed that all individuals make approach commitment in monetary exercises, 15 respondents $(3.75 \%)$ uncovered that just a few individuals contribute in financial exercises of the gathering and 5 respondents $(1.25 \%)$ said that not many individuals make commitment in pay creating exercises. It very well may be in this manner inferred that the majority of the individuals from SHG contribute similarly in the financial exercises of the gathering. In a few gatherings the commitments of a few individuals supposedly were inadequate with regards to, the explanation for this is the land area of those individuals.

Table 17: Self-employment after joining SHG

\begin{tabular}{|l|l|l|l|}
\hline Sl. No. & Self-Employed in areas of & No. of respondents & $\%$ Total \\
\hline 1. & Agriculture & 320 & $80 \%$ \\
\hline 2. & Livestock & 60 & $15 \%$ \\
\hline 3. & Business & 15 & $3.75 \%$ \\
\hline 4. & Nil & 05 & $1.25 \%$ \\
\hline & Total & 400 & $100 \%$ \\
\hline
\end{tabular}

Source: Fieldwork,

The table 4.26 delineates that $80 \%$ respondents got independent work in zones of farming, $15 \%$ in zones of animals, $3.75 \%$ began little scale business and $1.25 \%$ respondents have not taken up any individual business. The respondents opined that the preparation they got under SHGs helped them to upgrade their abilities in farming and domesticated animals which brought about better creation of vegetables, natural products, poultry and domesticated animals and brought maintainable financial additions.

Table 18: Income through individual business

\begin{tabular}{|l|l|c|c|}
\hline Sl. No. & \multicolumn{1}{|c|}{ Income from self-employment } & $\begin{array}{l}\text { No. of } \\
\text { respondents }\end{array}$ & $\%$ Total. \\
\hline 1. & Rs. $1000-4000$ & 360 & $90 \%$ \\
\hline 2. & Rs. $4001-8000$ & 15 & $3.75 \%$ \\
\hline 3 & Rs. $8001-12000$ & 2 & $0.5 \%$ \\
\hline 4. & More than Rs. 12000 & 0 & 0 \\
\hline 5. & Nil & 23 & $5.75 \%$ \\
\hline & Total & 400 & $100 \%$ \\
\hline
\end{tabular}


Table 18 demonstrates the individual pay through business and $90 \%$ respondents said that their salary differed between Rs.1000-4000 every month, 3.75\% respondents hold that their pay extended from Rs.4001-8000 and 0.5\% respondents have pay variety of Rs.8001-12000. The respondents in perspective of the above information have produced pay and methods for subsistence for themselves.

Table 19: Economic status of the respondents after joining SHG

\begin{tabular}{|l|l|l|l|}
\hline S1. No. & Economic Status & No. of respondents & $\%$ Total \\
\hline 1. & Totally dependent on spouse or family & 20 & $5 \%$ \\
\hline 2. & Dependent only few times & 300 & $75 \%$ \\
\hline 3. & Independent & 80 & $20 \%$ \\
\hline & Total & 400 & $100 \%$ \\
\hline
\end{tabular}

\section{Source: Fieldwork,}

The table 19 shows that $20 \%$ respondents have turned out to be monetarily independent and don't rely upon their family or spouse for satisfying essential needs. $75 \%$ still depended here and there on their mate's salary. 5\% respondents completely relied upon their life partner and family. Most of respondents who had turned out to be financially autonomous took credits from the SHGs and put it in little scale business of pieces of clothing, vegetables, piggery, poultry, gardening, conventional painstaking work and so on for money age.

Table 20: Participation of respondents in social awareness programmes

\begin{tabular}{|l|l|l|l|}
\hline Sl. No. & Participation & No. of respondents & $\%$ Total \\
\hline 1. & Always participate in all programmes & 340 & $85 \%$ \\
\hline 2. & Participate irregularly & 30 & $7.5 \%$ \\
\hline 3. & Hardly participate & 30 & $7.5 \%$ \\
\hline & Total & 400 & $100 \%$ \\
\hline
\end{tabular}

\section{Source: Fieldwork,}

Table 20 showcases that $85 \%$ respondents conceded that they generally partake in all projects composed by the gathering, $7.5 \%$ reacted that their investment were sporadic and just $7.5 \%$ respondents conceded that they barely take an interest in these projects. The respondents who consistently took an interest in these projects were seen to have more learning and increased more certainty about social issues, for example, aggressive behavior at home, wellbeing, sanitation, nourishment, instruction, liquor addiction, HIV AIDs and so forth when contrasted with the individuals who barely partook in such crusades.

Table 21: Leadership qualities after joining SHG

\begin{tabular}{|l|l|l|l|}
\hline S1. No. & Leadership & No. of respondents & $\%$ Total \\
\hline 1. & $\begin{array}{l}\text { Can address meetings, talk to officials, and lead } 300 \\
\text { the group. }\end{array}$ & $75 \%$ \\
\hline 2. & Can do so sometimes & 80 & $20 \%$ \\
\hline 3. & Feel Shy and hesitant & 20 & $05 \%$ \\
\hline & Total & 400 & $100 \%$ \\
\hline
\end{tabular}

Source: Fieldwork, 
Table 21 layouts that $75 \%$ respondents felt that they had created initiative characteristics, $20 \%$ respondents who were to some degree uncertain and $5 \%$ respondents felt timid or reluctant. It very well may be summed up that larger part of the respondents had created authority characteristics by joining SHGs. A few respondents had challenged panchayat decisions in the wake of joining SHGs, the President and different pioneers of SHG supposedly led the gathering towards a positive bearing, they likewise composed and drove encourages to make mindfulness on issues, for example, wellbeing, instruction, abusive behavior at home and so forth.

Table 22: Confidence building of respondents after joining SHG

\begin{tabular}{|l|l|l|l|}
\hline Sl. No. & Level of Confidence & No. of respondents & $\%$ Total \\
\hline 1. & Yes I have built confidence & 380 & $95 \%$ \\
\hline 2. & May be & 20 & $5 \%$ \\
\hline 3. & No I have not & 0 & 0 \\
\hline & Total & 400 & 100 \\
\hline
\end{tabular}

Source: Fieldwork,

It is obvious from the table that out of 400 respondents, 95\% respondents feel that they have picked up certainty subsequent to joining SHGs and just $5 \%$ respondents were uncertain. The respondents who felt that they have turned out to be progressively certain expressed that subsequent to joining SHGs they figured out how to address gatherings and have encountered a constructive change as a part of their identity. They said that they have fabricated valuable systems with individuals from the panchayat, NGOs, government and bank authorities and have turned out to be progressively trained in their lead.

Table 23: Decision making within the house after joining SHG

\begin{tabular}{|l|l|l|l|}
\hline S1. No. & Decision regarding & No. of respondents & $\%$ Total \\
\hline 1. & Family and children's education & 140 & $35 \%$ \\
\hline 2. & Buying land and other assets & 20 & $05 \%$ \\
\hline 3. & Spending own income & 190 & $47.5 \%$ \\
\hline 4. & Family business & 50 & $12.5 \%$ \\
\hline 5. & Nil & 0 & $0 \%$ \\
\hline & Total & 400 & 100 \\
\hline
\end{tabular}

Source: Fieldwork,

Table 23 features that 35\% ladies in SHGs could settle on choice with respect to family and youngsters' instruction, another $47.5 \%$ could spend their salary according to their will, $05 \%$ had an equivalent state in issues of purchasing area and resources and $2.5 \%$ as far as privately-owned company. In this manner from the information it is seen that ladies in SHGs have a voice in the family with respect to different issues. The respondents recognized that SHGs had given them a superior mental self portrait and their significant other and relatives had begun esteeming their choices. They felt that the independent work through SHGs had engaged them, expanded their dimension of certainty and made them progressively self-assured. Moreover, other relatives additionally began regarding their choices. 
Table 25: Assets bought after joining SHG

\begin{tabular}{|l|l|l|l|}
\hline Sl. No. & Assets & No. of respondents & $\%$ Total \\
\hline 1. & Land & 10 & $2.5 \%$ \\
\hline 2. & Jewellery & 120 & $30 \%$ \\
\hline 3. & Home Appliances & 220 & $55 \%$ \\
\hline 4. & Vehicle & 0 & $0 \%$ \\
\hline 5. & Nil & 50 & $12.5 \%$ \\
\hline & Total & 400 & 100 \\
\hline
\end{tabular}

Source: Fieldwork,

The above table shows that $55 \%$ respondents have purchased home apparatuses subsequent to joining SHG, 30\% have purchased gems, 2.5\% have purchased land and 12.5\% have not purchased anything in the wake of joining SHG. It is discovered that the majority of the respondents have expanded their benefits in the wake of joining SHG.

Table 26: Access of SHG members to NGOs, Bank and Government officials

\begin{tabular}{|l|l|l|l|}
\hline Sl. No. & Institutional support & No. of respondents & $\%$ Total \\
\hline 1. & Easy access to key persons, loans etc. & 390 & $97.5 \%$ \\
\hline 2. & Sometimes cannot be accessed & 10 & $2.5 \%$ \\
\hline 3. & No access & 0 & 0 \\
\hline & Total & 400 & 100 \\
\hline
\end{tabular}

\section{Source: Fieldwork,}

The field information displayed in table 46 accentuates that $97.5 \%$ respondents have simple access to the key people and authorities, $2.5 \%$ said that occasionally they couldn't be effectively gotten to. This shows the majority of the SHGs approach this work force and could undoubtedly meet them, benefit credits absent much trouble and talk about issues identifying with SHG.

Table 27: Loan taken by SHG members

\begin{tabular}{|l|l|l|l|}
\hline S1. No. & Loans taken for & No. of Respondents & $\%$ Total \\
\hline 1. & Medical treatment & 20 & $5 \%$ \\
\hline 2. & Individual invest in agriculture/ & & \\
\hline 3. & livestock/business & 220 & $55 \%$ \\
\hline 4. & For income generation of group & 80 & $20 \%$ \\
\hline 5. & For children's education & 20 & $5 \%$ \\
\hline & Total & 60 & $15 \%$ \\
\hline
\end{tabular}

Source: Fieldwork,

Table 27 proposes that $5 \%$ respondents take credits for restorative treatment, $55 \%$ respondents take advances for interest in agribusiness, domesticated animals and business, $20 \%$ for money creating movement of the gathering, $5 \%$ respondents to instruct youngsters and 15\% respondents for family 
utilization and different exercises like celebrations, marriage of child, little girl. Increasingly number of respondents has taken credits for interest in horticulture, domesticated animals and business.

Table 28: Total Savings done by the SHG

\begin{tabular}{|l|l|l|l|}
\hline Sl. No. & Amount Saved & No. of SHGs & $\%$ Total \\
\hline 1. & Rs. $10,000-30,000$ & 20 & $50 \%$ \\
\hline 2. & Rs. $30,001-60,000$ & 10 & $25 \%$ \\
\hline 3. & Rs. $60,001-90,000$ & 6 & $15 \%$ \\
\hline 4. & Rs. $90,001-1,20000$ & 4 & $10 \%$ \\
\hline 5. & Above Rs. $1,20,001$ & 0 & $0 \%$ \\
\hline & Total & 40 & 100 \\
\hline
\end{tabular}

\section{Source: Fieldwork,}

The table 28 features that 50\% SHGs have an all-out sparing of Rs.10,000-30,000, 25\% SHGs have spared 30,001-60,000, 15 \% SHGs have spared Rs.60,001-90,000 and 10\% SHGs have spared Rs.90,001$1,20,000$. The examination along these lines, focuses that the SHGs have created great measure of sparing.

Table 29: Problems faced while availing funds

\begin{tabular}{|l|l|l|l|}
\hline Sl. No. & Problem faced for availing Funds & No. of SHGs & $\%$ Total \\
\hline 1. & Yes & 30 & $75 \%$ \\
\hline 2. & No & 10 & $25 \%$ \\
\hline & Total & 40 & 100 \\
\hline
\end{tabular}

\section{Source: Fieldwork,}

Table 29 portrays that $75 \%$ respondents confronted issues while benefiting advances, appropriation and credit from banks and $25 \%$ respondents did not confront any trouble in profiting reserves. The examination in this manner, underlines that most SHG individuals did not confront any financing issues. A not very many SGHs confronting issues expressed that the bank authorities some of the time postponed the exchange of assets that made issues for the individuals who needed to travel long separations and brought about exercise in futility and expanded their movement costs. It likewise deferred their introduction of financial exercises.

Table 30 Loan defaulters

\begin{tabular}{|l|l|l|l|}
\hline S1. No. & Loan defaulters present in SHG & No. of SHGs & $\%$ Total \\
\hline 1. & Yes & 16 & $40 \%$ \\
\hline 2. & No & 24 & $60 \%$ \\
\hline & Total & 40 & 100 \\
\hline
\end{tabular}

\section{Source: Fieldwork,}

Table 30 mirrors that $40 \%$ of SHGs don't have advance defaulters and $60 \%$ SHG have individuals who have not reimbursed the advance sum on time. It very well may be said that the quantity of advance defaulters is low in the example SHGs. The individuals from the SHG that asserted the nonreimbursement of advances kept up that, the gathering individuals neglected to reimburse advances in light of the fact that their interests in business and different exercises had not yielded positive 
outcomes. Now and again the advancement was moderate henceforth it caused a deferral in credit reimbursement. Diverse investigations on SHGs directed in Arunachal Pradesh, West Bengal, Tamil $\mathrm{Nadu}$, Kerala and Orissa have confronted market related issues. The moving of products delivered by gathering turns into a noteworthy issue for SHGs all through the nation.

Table 31: Do you participate in social awareness programmes organised by the village?

\begin{tabular}{|l|l|l|l|}
\hline S1. No. & Participation & No. of respondents & $\%$ Total \\
\hline 1 & I do participate in all programmes & 4 & $10 \%$ \\
\hline 2. & I participate irregularly & 6 & $15 \%$ \\
\hline 3. & I don't participate & 30 & $75 \%$ \\
\hline & Total & 40 & 100 \\
\hline
\end{tabular}

Source: Fieldwork,

The table 31 showcases that $75 \%$ respondents don't take an interest in social mindfulness programs sorted out by the town, $15 \%$ reacted that they once in a while take an interest in such projects and $10 \%$ respondents guaranteed that they consistently take an interest in social mindfulness programs. Accordingly it very well may be pondered that ladies who are not SHG individuals normally don't take an interest in social mindfulness battles sorted out by the town.

Table 32: Do you have the confidence to address meetings and speak in public?

\begin{tabular}{|l|l|l|l|}
\hline Sl. No. & Level of confidence & No. Of Respondents & $\%$ Total \\
\hline 1. & Yes, I am fully confident & 4 & $10 \%$ \\
\hline 2. & May be Sometimes & 16 & $40 \%$ \\
\hline 3. & No I am not confident & 20 & $50 \%$ \\
\hline & Total & 40 & 100 \\
\hline
\end{tabular}

Source: Fieldwork,

From the field information, it was discovered that, 10 respondents felt that they are completely sure to address gatherings or talk out in the open, $40 \%$ respondents said that they may once in a while have the certainty to address gatherings and talk in broad daylight and 50\% reacted they are not sufficiently sure. In this manner it very well may be accepted that a large portion of the respondents who are not associated with SHG are not sufficiently sure.

Table 33: Are you self-employed?

\begin{tabular}{|l|l|l|l|}
\hline Sl. No. & Self-Employed & No. of respondents & $\%$ Total \\
\hline 1. & Yes & 16 & $40 \%$ \\
\hline 2. & No & 24 & $60 \%$ \\
\hline & Total & 40 & 100 \\
\hline
\end{tabular}

The table 33 implies that just $40 \%$ respondents are independently employed and the staying $60 \%$ respondents have no methods for independent work. The discoveries therefore mirrored that respondents who are not in SHG have not accomplished independent work. 
RESULT ANALYSIS

\section{Statistical Tools}

In order to study analyse the impact of SHG's on income and employment in Mahabubnagar district in Telangana State the following variables will be used.

\section{Dependent variable - Income and Employment}

\section{Independent variables}

- Age

- Education

- Occupation

- farm

- investment

- income

Specification of the Model

To the analyse the impact of SHG's on income and employment, a logit model will be used in the analysis of individual SHG'S Members got impact of income and Employment generation. The model uses various SHG'S households as the factors influencing income and Employment generation.

$P_{i}=E$

$P_{i}=$ Probability that SHG member got benefited

$\mathrm{b}_{1}=$ constant term

$b_{k}=$ coefficients

$X_{k}=$ for $K=1 \ldots 6$, are the independent variables and subscript $i$ denotes $i$ th observation.

$\mathrm{K}_{1}=$ Age

$\mathrm{K}_{2}=$ Education

$\mathrm{K}_{3}=$ Occupation

$\mathrm{K}_{4}=$ Size of the Employment

$\mathrm{K}_{5}=$ investment

$\mathrm{K}_{6}=$ income

Let

$\mathrm{Z}_{\mathrm{i}}=\mathrm{b}_{1}+\sum \mathrm{b}_{\mathrm{k}} \mathrm{X}_{\mathrm{ik}}$

Then

$P_{i}=$

As $Z_{i}$ ranges from $-\infty$ to $+\infty, P_{i}$ ranges from 0 to 1 and $P_{i}$ is non-linearly related to $Z_{i}$.

In estimable form, the model is,

$\mathrm{L}_{\mathrm{i}}=\mathrm{Ln}$

Where $\mathbf{L}$ is the logit it shows how the log odds in favour of Health insurance purchased change as the respective independent variable changes. 
Table 34: Logistic regression- Coefficient of the model

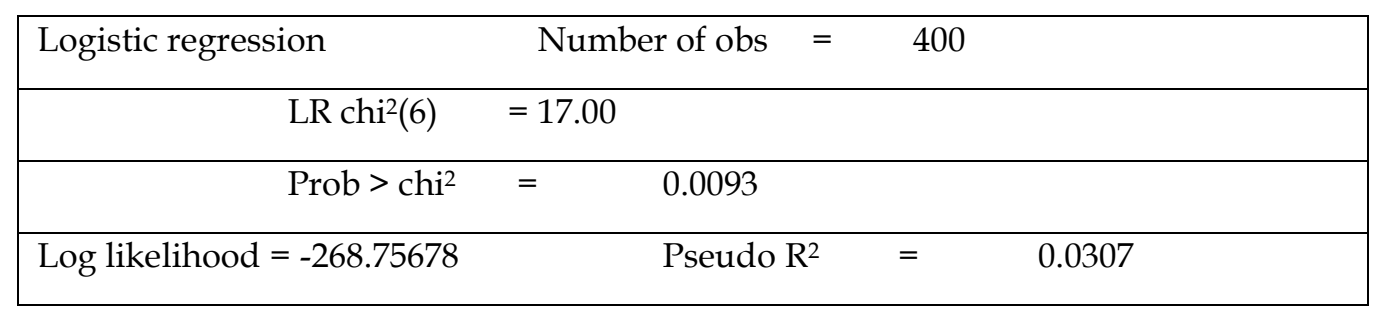

Table 35

\begin{tabular}{|l|l|l|l|l|l|l|}
\hline ben & Coeff. & Std. Err. & $\mathrm{z}$ & $\mathrm{P}>\mathrm{z}$ & {$[95 \%$ Conf. } & interval \\
\hline age & -.246257 & .150632 & -1.63 & 0.102 & -.5414903 & .0489763 \\
\hline edu & -.0082751 & .089552 & -0.09 & 0.926 & -.1837941 & .1672438 \\
\hline ocua & -.0535996 & .1168355 & -0.46 & 0.646 & -.2825929 & .1753938 \\
\hline emp & .1800376 & .2122889 & 0.85 & 0.396 & -.2360409 & .5961161 \\
\hline inv & -.0001089 & .00004 & -2.72 & 0.007 & -.0001873 & -.0000304 \\
\hline inc & .0000908 & .0000307 & 2.95 & 0.003 & .0000305 & .000151 \\
\hline cons & -.0428089 & .5664311 & -0.08 & 0.940 & -1.152993 & 1.067376 \\
\hline
\end{tabular}

$\mathrm{P}=$ Probability that a sample SHG member got benefited.

\section{CONCLUSION}

The odds ratio in favor of income and employment generation, the coefficient of the model indicates the percentage change in odds ratio for 1 unit change in the independent variable.

Accordingly the odds ratio is favourable for the changes in income, Age, Education, Occupation, Size of employment and investments. The variables like income and investment are statistically significant.

Similar is the case for the coefficient of the model where the coefficient of the significance where above mentioned variable.

The variables which are Age, Education, Occupation, Size of employment, Income and investments have impact of SHGs on their livelihood. But statistically Income and Investment are significant. These variables are impact on SHGs livelihood.

\section{REFERENCES}

1. R.Das Gupta (2006), "An Architectural plan for a Microfinance institutional network", Economic and political weekly $18^{\text {th }}$ March 2006, pp. 1095-1100

2. Madhura Swaminathan (2007), "The Micro Credit Alternative?", Economic and Political weekly, 31,March 2007,PP. 1171-1175.

3. K. K Tripathy \& I. G. Tripathy (2007), "Microfinance and Self-Employment initiatives under SGSY: A review of intension and realities", Productivity, Vol.47, No.4, January-March, 2007, pp 387-393. 
4. MD. Saiful Islam (2004), "who benefits, how benefits: the political economy of Grameen Bank's micro credit program in rural Bangladesh", Indian J Soc Dev, Vol.4, No.1, June 2004, pp.1-17.

5. Arun Anand (2005), “Micro-finance-A key to poverty alleviation", Janata, 23October 2005, pp.810

6. Aloysius P Fernandez (2007), "A Microfinance institution with a difference", economic and political weekly, March 31 ${ }^{\text {st }} 2007$, pp. 1185-1189

7. Christopher Dunford (2000), “The holy grail of microfinance: helping the poor and sustainable?" Small enterprise development Vol.11, No.1, pp. 40-45

8. Karmakar K G (1999), “Rural Credit and Self help groups: Microfinance needs and concepts in India", SAGE Publications, New Delhi.

9. Versluvysen, Eugene (2000), "Defying the odds: Banking for the poor", Connecticut, Kumarian press, 2000.

10. Bavaiah and Dr. J Narasimha Rao (2006), "women empowerment and Microfinance", Select country experience, Microfinance development review, Association of Ethiopian Microfinance institutions (AEMFI), Addis Ababa, Vol.5, No.1, 2006.

11. Piyanka dongre and Ajay pethe (2020)," Effectiveness of micro finance in sustainable rural development -A study in wardha district", International journal of business, management and allied sciences (ijbmas), Vol.7. Issue.1.2020 (Jan-Mar), pp 11-20. 